\title{
How increased atmospheric carbon dioxide and 'The Law of the Minimum' are contributing to environmental obesity
}

\author{
Como o aumento no dióxido de carbono atmosférico e a 'Lei dos Mínimos' estáo \\ contribuindo para a obesidade ambiental
}

\section{James Bryan Cotner ${ }^{1 *}$ []}

\author{
${ }^{1}$ Department of Ecology, Evolution and Behavior, University of Minnesota-Twin Cities, 1479 \\ Gortner Ave, Saint Paul, Minessota, MN, 55108, USA \\ *e-mail: cotne002@umn.edu
}

Cite as: Cotner JB. How increased atmospheric carbon dioxide and 'The Law of the Minimum' are contributing to environmental obesity. Acta Limnologica Brasiliensia, 2019, vol. 31, e113.

\begin{abstract}
Justus von Liebig observed that one could greatly increase agricultural yields by adding relatively small quantities of nitrogen $(\mathrm{N})$, phosphorus $(\mathrm{P})$ and potassium $(\mathrm{K})$ to soils. This finding led to the most recent agricultural revolution. But because most plants and microbes can be non-homeostatic with respect to their biomass elemental composition, adding nutrients can lead to disproportional increases in some macro-elements in organisms, while micronutrient content decreases. Increased $\mathrm{CO}_{2}$ in the atmosphere is an important driver of climate change, but it is also an important driver of changing biomass content and ecosystem stoichiometry. Increased $\mathrm{CO}_{2}$ has contributed to excess carbon in biomass and ecosystems, a state which could be contributing to changes in metabolism which I liken to metabolic diseases and 'environmental obesity'. Here I defined environmental obesity as excess $\mathrm{C}$ accumulation relative to other elements in the environment. A warming climate is certainly motivation enough for humans to do whatever is necessary to decrease use of fossil fuels. However, increased carbon has detrimental health outcomes through effects on our food in natural and agricultural systems and suggests that $\mathrm{CO}_{2}$ is not 'just an environmental problem', but also a human health problem.
\end{abstract}

Keywords: stoichiometry; Liebig; environmental obesity; homeostasis; carbon.

Resumo: Justus von Liebig observou que era possível aumentar a produção agrícola adicionando pequenas quantidades de nitrogênio $(\mathrm{N})$, fósforo $(\mathrm{P})$ e potássio $(\mathrm{K})$ aos solos. Essa descoberta levou a mais recente revolução agrícola. Contudo, uma vez que a maioria das plantas e microrganismos podem ser não-homeostáticos em relação a composição química elementar da sua biomassa, adicionar nutrientes pode resultar em aumentos desproporcionais de alguns macro-elementos nos organismos, enquanto os micronutrientes declinariam. O aumento nas concentraçóes de $\mathrm{CO}_{2}$ na atmosfera é um importante direcionador nas mudanças climáticas, mas também pode ter um importante papel na mudança da composição química da biomassa e na estequiometria dos ecossistemas. Os aumentos nas concentraçóes de $\mathrm{CO}_{2}$ na atmosfera tem contribuído para o excesso de carbono (C) na biomassa e nos ecossistemas, um estado que pode estar contribuindo para mudanças no metabolismo, que eu comparo com uma doença metabólica e "obesidade ambiental". Aqui eu defino obesidade ambiental como o acúmulo excessivo de $\mathrm{C}$ relativamente a outros elementos no ambiente. $\mathrm{O}$ aquecimento do clima é, certamente, motivação suficiente para os seres humanos fazerem o que for necessário para reduzir o uso de combustíveis fósseis. Contudo, o aumento do carbono tem implicaçóes muito negativas para a saúde através de efeitos sobre a nossa comida em sistemas naturais e agrícolas e, sugere que o $\mathrm{CO}_{2}$ náo é somente um problema ambiental, mas também um problema de saúde humana.

Palavras-chave: estequiometria; Liebig; obesidade ambiental; homeostase; carbono. 


\section{Liebig and Stoichiometric Flexibility}

Earth supports an unprecedented population of humans, currently at about 7.7 billion of us, in large part because of innovative agriculture that greatly increased yields of plants by adding nutrients that are commonly limiting to biomass production. The global implementation of these practices has led to the Green Revolution, allowing us to feed an ever-growing population. The idea of adding potentially limiting nutrients, referred as 'law of the minimum' was originally proposed by Carl Sprengel and popularized by Justus von Liebig (van der Ploeg et al., 1999). This idea has led to Liebig being referred to as the 'father of fertilizers' because it eventually led to our present-day practice of adding nitrogen $(\mathrm{N})$, phosphorus $(\mathrm{P})$, and potassium $(\mathrm{K})$ to soils to increase yields, which has been critical to the capability of supporting such a large human population.

A key aspect of the law of the minimum is the idea that the elemental composition of plants is fixed. For example, if there is a deficiency of nitrogen $(\mathrm{N})$ in soil or lake water, the medium will produce less plant biomass, than if $\mathrm{N}$ were plentiful. Although $\mathrm{N}$ is continually being made available to plants through multiple processes such as atmospheric deposition and regeneration processes in the soil or water, the rate at which new plant material is produced is solely controlled by the rate at which 'new' $\mathrm{N}$ becomes available, since it is the rate limiting nutrient in this scenario. This is analogous to an assembly line--if you want to make a new automobile, you have to have all of the parts for the automobile on hand. Automobile factories have limited space, so they are managed to insure that they have 'storage bins' of all of the parts they need and when one of those stores is depleted, let's say the transmission, they cannot make any more cars until it gets re-supplied. You cannot have a car without a transmission and you cannot have a plant without $\mathrm{N}$.

But recent work in our group and others suggests that plants and microbes may not be as much like an automobile assembly line as Liebig may have presumed (never mind that autos and auto assembly lines did not exist at the time!). Liebig assumed that plants and microbes had specific elemental compositions and that there was little that a plant could do when the supply of one of the 'limiting' nutrients ran out. In other words, if a plant required a molar nitrogen $(\mathrm{N})$ to phosphorus (P) ratio of about $16: 1 \mathrm{~N}: \mathrm{P}$, i.e., the Redfield ratio, and the supply ratio was only 8:1 N:P, then plants would regulate biomass production to match the $\mathrm{N}$ supply rates at a lower yield, but maintain biomass at a uniform 16:1 N:P ratio. For example, they could either excrete or respire excess carbon and phosphorus to match the $\mathrm{N}$ supply ratio.

But it turns out that microbes and plants can be fairly plastic, i.e., they have flexible stoichiometry, and they can change their biomass ratios to closely match the supply rates in the environment. To return to the assembly line analogy, it is as if plants and microbes are putting the 'storage bin' right in the automobile. For example, we tested the idea that microbes are relatively inflexible, as Liebig presumed, by providing substrates for bacteria that had a carbon (C) to P ratio of about 200,000:1. The presumed requirement for aquatic algae and bacteria for C:P is the Redfield ratio which is 106:1 C:P so the 'food' we provided bacteria that were collected from a temperate lake was extremely deficient in P. If Liebig was correct, then the C:P of the bacterial biomass should have been pretty close to $106 \mathrm{C}: 1 \mathrm{P}$, but that was not the case. The C:P of bacterial biomass was over 10,000:1 in some cases (Godwin \& Cotner, 2015a). Furthermore, the N:P ratio of bacterial biomass was 2,000:1, well over the expected ratio of about $16: 1$. In other words, there was at least one bacterium in the community that we inoculated that was able to change its biomass composition to more closely match the availability of their resources, allowing them to maintain a relatively high biomass yield.

Similar flexibility has been observed in phytoplankton when the dissolved $\mathrm{CO}_{2}$ concentration $\left(\mathrm{pCO}_{2}\right)$ was manipulated. Both the C:N and C:P of Rhodomonas increased greatly at elevated $\mathrm{pCO}_{2}$ in culture (Schoo et al., 2013). The C: $\mathrm{N}$ ratio increased to nearly 20 and the C:P ratio increased to nearly 1200 at a $\mathrm{pCO}_{2}$ of $800 \mathrm{ppm}$. In another experiment, the C:P of algal biomass increased to over 1500:1 at a $\mathrm{pCO}_{2}$ of about 10x current ambient levels (Urabe et al., 2003). Similar stoichiometric effects have been observed in terrestrial plants and crops grown at elevated $\mathrm{pCO}_{2}$ (Loladze, 2002, 2014).

What does it mean? It suggests there are plants and microbes that are growing in the environment that are extremely flexible in their biomass composition. One of the reasons this is important to natural ecosystems is that it leads to negative feedback between the supply ratios of nutrients into an ecosystem, for instance a lake, and the export of nutrients out of the lake. For example, imagine a lake or reservoir where the N:P supply ratio is 
higher than a plant's requirement, maybe a $30 \mathrm{~N}: 1 \mathrm{P}$, while the plant's requirement is near the Redfield ratio of $16 \mathrm{~N}$ : $1 \mathrm{P}$. If organisms growing in the lake remove $\mathrm{N}$ and $\mathrm{P}$ at a ratio of 16:1, the downstream export ratio will be even higher, maybe 60-100:1 depending on how much growth actually occurs in the lake or reservoir. Downstream lakes or reservoirs will exacerbate this problem further to the point where the N:P ratio exported to the oceans could be extremely high, perhaps greater than 200:1.

The actual ratio of material exported from terrestrial systems via freshwaters is estimated to be about 24N:1P (Maranger et al., 2018). Clearly other processes are occurring as organic matter moves from the land to the sea, such as denitrification and other inputs that may decrease N:P ratios. But in the context of our work showing that communities can be quite flexible, it suggests that this flexibility could be an important mechanism maintaining stoichiometric stability in ecosystems. This may be achieved via multiple mechanisms. It could be that individual organisms are able to change their biomass composition to match their substrates or it could be that at high N:P supply ratios, organisms with high N:P ratios are selected for. In reality, both of these processes are likely occurring. We have shown that both communities (Godwin \& Cotner, 2015a, b) and individual strains of bacteria (Godwin \& Cotner, 2018) can be quite flexible, with some strains changing their biomass C:P ratios by more than $1000 \%$ and their N:P ratios by more than 800\% (Godwin \& Cotner, 2018).

\section{Stoichiometric Flexibility and Global Change Processes}

The capacity of plants and microbes to respond to variation in elemental supply ratios is particularly relevant to global change dynamics. Humans have perturbed the global $\mathrm{C}, \mathrm{N}$ and $\mathrm{P}$ cycles to unprecedented extents (Falkowski et al., 2000). The main processes driving changes in $\mathrm{C}$ perturbations over the last two hundred years or so have been fossil fuel burning and land use changes which currently are releasing an additional $10 \mathrm{Pg}$ of carbon per year into the atmosphere primarily as $\mathrm{CO}_{2}$ (Figure 1). For $\mathrm{N}$ and $\mathrm{P}$, the main driver has been the extensive use of fertilizers to increase yields of agricultural systems. Humans have had the greatest quantitative effect on the $\mathrm{C}$ cycle, but the effects of humans on the $\mathrm{N}$ and $\mathrm{P}$ cycles relative to natural cycling processes is more than ten times greater than the C cycle.

An intriguing aspect of our work with aquatic heterotrophic bacteria has to do with how the

\section{Environmental Obesity}

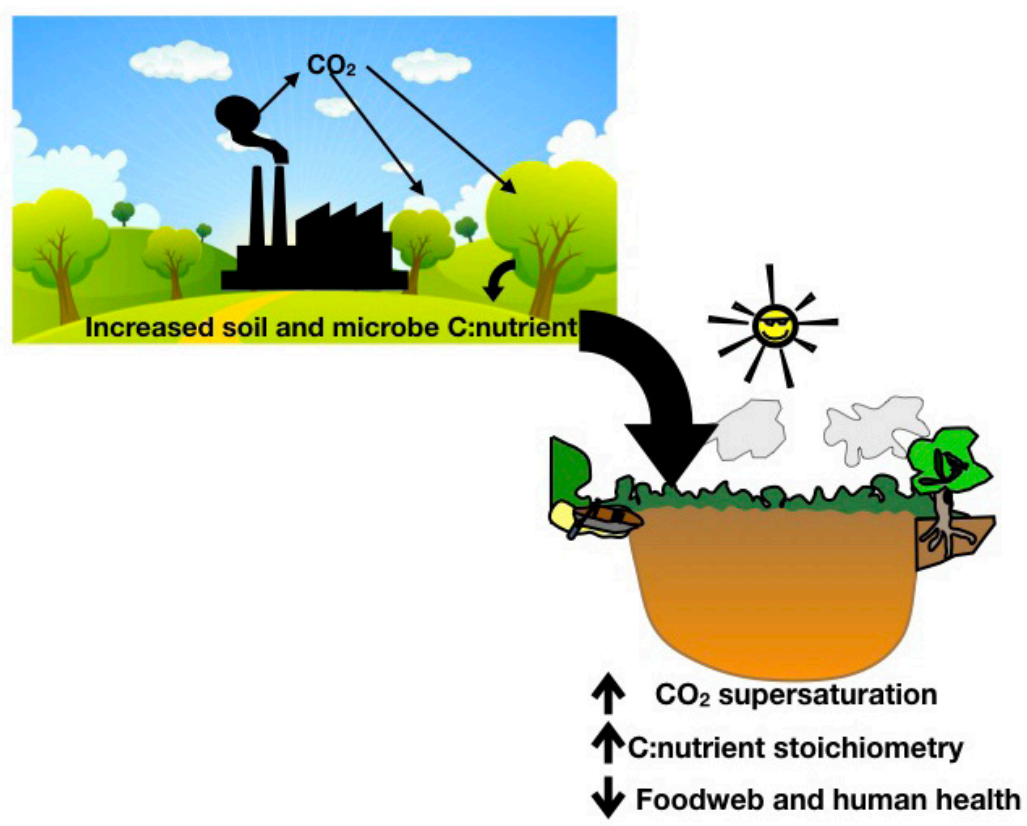

Figure 1. Hypothesized effects of increased $\mathrm{CO}_{2}$ on ecosystems. Fossil fuel burning leads to increased $\mathrm{CO}_{2}$ in the atmosphere which increases the $\mathrm{C}$ :nutrient ratios of terrestrial plants and soil microbes, as well as the material that is exported to freshwaters. Similarly, the C:nutrient ratios of freshwaters increase due to excess $\mathrm{CO}_{2}$ in the atmosphere but, perhaps more importantly, from exported organic and inorganic matter from terrestrial systems. 
composition of the cell changes for non-limiting nutrients and carbon. Carbon composition and quantity can change significantly when microbes go from P-deficiency to P-sufficiency. In a survey of over 130 strains of bacteria, we observed a median increase in the C:P ratio of $142 \%$ going from a medium with a C:P ratio of $100: 1$ to a medium with a C:P ratio of 10,000:1. A significant aspect of these changes in biomass composition has to do with minimizing P quotas at low P availability giving higher $\mathrm{C}: \mathrm{P}$ ratios, but somewhat surprisingly, a larger component contributing to these changes were related to the carbon quotas (Phillips et al., 2017; Godwin \& Cotner, 2018). At low relative growth rates, the carbon quota for Brevundimonas more than tripled with two orders of magnitude increase in the supply C:P ratio. Carbon clearly was not a limiting nutrient particularly at the highest C:P ratios. But if carbon in cells continues to increase even when it is not limiting, it would facilitate these negative feedbacks.

An important question that has been little addressed, particularly in freshwaters, is the potential role of increased $\mathrm{CO}_{2}$ in the atmosphere on productivity and stoichiometry. The latter is very relevant to the issue of stoichiometric flexibility due to the fact that increased carbon availability in freshwaters as well as terrestrial systems could be contributing to changing biomass and ecosystem stoichiometry, leading to higher C: nutrient ratios. Unlike the open ocean where $\mathrm{pCO}_{2}$ is primarily controlled by physical equilibration of the surface ocean with the atmosphere, most freshwater systems experience a combination of physical and biological control due to their smaller size and greater biomass both in freshwaters but also in the surrounding watershed.

The physical driver of increased $\mathrm{pCO}_{2}$ is the same for marine and freshwater systems, i.e., increased atmospheric $\mathrm{CO}_{2}$ concentrations and equilibration with water, but the degree of biological control can vary extensively in freshwaters due to the variation in size, geology, watershed and the biological composition. This means that the physical signal can be more difficult to detect. Relatedly, Cole et al. (1994) demonstrated that globally, lakes had somewhere between 3-16 times the $\mathrm{pCO}_{2}$ concentrations of the atmosphere, which we have ascribed in recent years to both heterotrophic respiration in freshwaters as well as import of $\mathrm{pCO}_{2}$ from the watershed (Stets et al., 2009; McDonald et al., 2013). In a global survey of streams, $\mathrm{pCO}_{2}$ levels averaged eight times the concentrations that would be predicted by equilibration with the atmosphere (Raymond et al., 2013).

Consequently, watershed biogeochemical factors are likely to be important in small, freshwater systems, in particular. Increased terrestrial productivity as a result of both warming and increased $\mathrm{CO}_{2}$ concentrations as well as increased export of dissolved organic carbon (DOC) and dissolved inorganic carbon (DIC) suggest that $\mathrm{pCO}_{2}$ should increase in the coming decades (Adrian et al., 2009; Ou et al., 2015; Hasler et al., 2016). There is a pattern of increased export of DOC into freshwater ecosystems that has been commonly observed in the Northern Hemisphere (Freeman et al., 2001; Monteith et al., 2007; Urban et al., 2011). Presumably increased terrestrial production and/or changes in stoichiometry could be playing a role in this phenomenon, although several other hypotheses have been suggested, such as alkalinization of soils (Monteith et al., 2007), increased temperatures (Freeman et al., 2001; Pastor et al., 2003), and urbanization (Noacco et al., 2017). Harrison et al. (2005) modeled a DOC:DON:DOP export ratio to the coastal region of 732:37:1 but we do not know how this has changed over time. Nonetheless, there is evidence in the ocean of increased DOC:DOP ratios in recent decades (Church et al., 2002; Aminot \& Kérouel, 2004). So, the idea that increased atmospheric $\mathrm{CO}_{2}$ could be changing the stoichiometry of material exported to and from freshwaters cannot be ignored. For inorganic C, a recent study analyzing data from four German reservoirs concluded that $\mathrm{pCO}_{2}$ is increasing by about $16 \mu \mathrm{atm} \mathrm{yr}^{-1}$ with a concomitant decreased in $\mathrm{pH}$, perhaps an indication that the physical influence of increased $\mathrm{CO} 2$ in the atmosphere is detectable even against a great deal of biogeochemical processing in the reservoirs and the surrounding watershed. A study in the Laurentian Great Lakes predicted that $\mathrm{pH}$ should decrease at rates similar to decreases in the oceans in the next 80 years (Phillips et al., 2015), driven by increased $\mathrm{CO}_{2}$ concentrations in the atmosphere.

Nonetheless, it seems that increased $\mathrm{CO}_{2}$ in the atmosphere, watershed dynamics (increased productivity and DOC and dissolved inorganic $\mathrm{C}$ [DIC] export) and climate are leading to increased $\mathrm{pCO}_{2}$ in freshwaters. What are the stoichiometric consequences of this? An increase of $\mathrm{pCO}_{2}$ in a Norwegian fjord led to increased carbon uptake and increased C:P and N:P ratios with important food web consequences (Bellerby et al., 2008; 
Riebesell et al., 2008; Van De Waal et al., 2010). In another experiment in a marine system, increased $\mathrm{pCO}_{2}$ again led to increased C:P, and increased N-fixation led to increased N:P ratios (Hutchins et al., 2007). In a simulated freshwater experiment, a similar result was observed whereby C:P ratios of phytoplankton increased and herbivore growth decreased despite increased phytoplankton abundance (Urabe et al., 2003).

In fact, free-air $\mathrm{CO}_{2}$ enrichment (FACE) experiments on terrestrial landscapes suggest that there can be measurable changes in stoichiometry with increased $\mathrm{CO}_{2}$ concentrations. In a meta-analysis of nearly 400 studies, Du et al. (2019) concluded that the C:P ratios of plants are increasing due to increased carbon dioxide in the atmosphere. Recent work with these experimental systems has demonstrated that productivity increases at higher carbon dioxide concentrations as well. Unfortunately, there have not been any FACE experiments that have been performed in freshwater systems, but smaller scale experiments suggest similar results as in Urabe et al. (2003). Also, similar to marine systems, increased $\mathrm{CO}_{2}$ disrupts the capacity of aquatic herbivores to sense their prey (Weiss et al., 2018).

In many of these experiments in terrestrial systems, freshwaters and the oceans, there seems to be important effects of excess $\mathrm{CO}_{2}$ on stoichiometry, with the predominant effect being increased carbon content and a dilution of other important elements. While most of the work done in ecosystems focuses on macroelements such as $\mathrm{C}, \mathrm{N}$ and $\mathrm{P}$, more recently it has been shown via FACE experiments that increased carbon dioxide is diluting the concentrations of important microelements, such as $\mathrm{Fe}$ and $\mathrm{Zn}$ in our food, as well as protein (Gifford et al., 2000; Loladze, 2014), and the decreased concentrations of these micronutrients can have negative effects on humans, often leading to metabolic disorders. A study examining the nutrient content of garden crops from the 1950s to 1999 demonstrated declines in protein, Fe and P over that time period (Davis et al., 2004). Roughly $30 \%$ of the world's population lives in regions where $60 \%$ of dietary iron and zinc comes from C3 crops that are strongly impacted by increasing $\mathrm{CO}_{2}$ concentrations with important health effects such as anemia, hypertension, and growth and metabolic disorders such as obesity and diabetes, among others. One of the mechanisms that the body employs for dealing with micronutrient deficiencies where food supplies are not limiting, as in Western countries, is overcompensation, a phenomenon where eating to fulfill a $\mathrm{Fe}, \mathrm{Zn}$ or protein requirement can result in excess calorie intake, potentially increasing the potential for development of obesity (Raubenheimer et al., 2015).

Given that we have evidence from both natural ecosystems and from our food resources that excess $\mathrm{CO}_{2}$ is increasing the $\mathrm{C}$ :nutrient and $\mathrm{C}$ :micronutrient composition of biomass, it raises the stakes regarding 'the $\mathrm{CO}_{2}$ problem'. Yes, increased $\mathrm{CO}_{2}$ is contributing to a warmer Earth with changing distributions of precipitation and more extreme climate in general (Ciais et al., 2013). But it is also making us less healthy via the food we eat. In many ways, all of the excess $\mathrm{CO}_{2}$ in the atmosphere is contributing to an 'obese environment' that, in turn, is having detrimental effects on human health at global scales. Obesity and other metabolic disorders are increasingly problematic in many parts of the world and there are many well-documented causes completely unrelated to the stoichiometry of our food, such as decreased activity, increased consumption of processed foods, etc., but in the background of all these other causes is a food supply that is increasingly carbon-rich and micro- and macro-nutrient poor. Many of the experiments that have been done already with added $\mathrm{CO}_{2}$ give us an idea of how carbon-rich or perhaps 'obese' ecosystems behave, but the long-term effects of an obese food web have not been addressed. Therefore, there is a great deal of work that still needs to be addressed in the future, particularly in freshwater ecosystems. One of the most important areas should address how changes in the availability of carbon affect plant and microbial community composition. It is well-known that increased $\mathrm{CO}_{2}$ changes the balance between $\mathrm{C} 3$ and $\mathrm{C} 4$ plants but it could be important to determine how it affects the balance between homeostatic and non-homeostatic organisms.

\section{References}

ADRIAN, R., O'REILLY, C.M., ZAGARESE, H., BAINES, S.B., HESSEN, D.O., KELLER, W., LIVINGSTONE, D.M., SOMMARUGA, R., STRAILE, D., VAN DONK, E., WEYHENMEYER, G.A. and WINDER, M. Lakes as sentinels of climate change. Limnology and Oceanography, 2009, 54(6), 2283-2297. http://dx.doi.org/10.4319/ lo.2009.54.6_part_2.2283. PMid:20396409.

AMINOT, A. and KÉROUEL, R. Dissolved organic carbon, nitrogen and phosphorus in the N-E Atlantic and the N-W Mediterranean with particular reference 
to non-refractory fractions and degradation. Deep Sea Research Part I: Oceanographic Research Papers, 2004, 51(12), 1975-1999. http://dx.doi.org/doi:10.1016/j. dsr.2004.07.016.

BELLERBY, R.G.J., SCHULZ, K.G., RIEBESELL, U., NEILL, C., NONDAL, G., HEEGAARD, E., JOHANNESSEN, T. and BROWN, K.R. Marine ecosystem community carbon and nutrient uptake stoichiometry under varying ocean acidification during the PeECE III experiment. Biogeosciences, 2008, 5(6), 1517-1527. http://dx.doi.org/10.5194/ bg-5-1517-2008.

CHURCH, M. J., DUCKLOW, H. W. and KARL, D. M. Multiyear increases in dissolved organic matter inventories at station ALOHA in the North Pacific Subtropical Gyre. Limnology and Oceanography. 2002, 47(1), 1-10. https://doi.org/10.4319/ lo.2002.47.1.0001.

CIAIS, P., SABINE, C. and BALA, G. Climate change 2013 - the physical science basis. Working group I contribution to the fifth assessment report of the intergovernmental panel on climate change. In: P. CIAIS, C. SABINE and G. BALA. Carbon and other biogeochemical cycles. Cambridge: Cambridge University Press, 2013, pp. 465-570. http://dx.doi. org/10.1017/CBO9781107415324.015.

COlE, J. J., CARACO, N. F., KLING, G. W. and KRATZ, T. K. Carbon dioxide supersaturation in the surface waters of lakes. Science, 1994, 265(5178),1568-1570. http://dx.doi.org/10.1126/ science.265.5178.1568.

DAVIS, D.R., EPP, M.D. and RIORDAN, H.D. Changes in USDA food composition data for 43 garden crops, 1950 to 1999 . Journal of the American College of Nutrition, 2004, 23(6), 669-682. PMid:15637215.

DU, C., WANG, X., ZHANG, M., JING, J. and GAO, Y. Effects of elevated CO2 on plant C-N-P stoichiometry in terrestrial ecosystems: a metaanalysis. The Science of the Total Environment, 2019, 650(Pt 1), 697-708. http://dx.doi.org/10.1016/j. scitotenv.2018.09.051. PMid:30212700.

FALKOWSKI, P., SCHOLES, R.J. and BOYLE, E. The global carbon cycle: a test of our knowledge of earth as a system. Science, 2000, 290(5490), 291-296. http:// dx.doi.org/10.1126/science.290.5490.291.

FREEMAN, C., EVANS, C.D., MONTEITH, D.T., REYNOLDS, B. and FENNER, N. Export of organic carbon from peat soils. Nature, 2001, 412(6849), 785. http://dx.doi.org/10.1038/35090628. PMid:11518954.

GIFFORD, R.M., BARRETT, D.J. and LUTZE, J.L. The effects of elevated [CO2] on the C:N and C:P mass ratios of plant tissues. Plant and Soil, 2000, 224(1), 1-14. http://dx.doi.org/10.1023/A:1004790612630.
GODWIN, C.M. and COTNER, J.B. Aquatic heterotrophic bacteria have highly flexible phosphorus content and biomass stoichiometry. The ISME Journal, 2015a, 9(10), 2324-2327. http://dx.doi. org/10.1038/ismej.2015.34. PMid:25798755.

GODWIN, C.M. and COTNER, J.B. Stoichiometric flexibility in diverse aquatic heterotrophic bacteria is coupled to differences in cellular phosphorus quotas. Frontiers in Microbiology, 2015b, 6, 159. http://dx.doi.org/10.3389/fmicb.2015.00159. PMid:25774154.

GODWIN, C.M. and COTNER, J.B. What intrinsic and extrinsic factors explain the stoichiometric diversity of aquatic heterotrophic bacteria? The ISME Journal, 2018, 12(2), 598-609. http://dx.doi. org/10.1038/ismej.2017.195. PMid:29171840.

HARRISON, J.A., CARACO, N. and SEITZINGER, S.P. Global patterns and sources of dissolved organic matter export to the coastal zone: results from a spatially explicit, global model. Global Biogeochemical Cycles, 2005, 19(4), 1-16. http:// dx.doi.org/10.1029/2005GB002480.

HASLER, C.T., BUTMAN, D., JEFFREY, J.D. and SUSKI, C.D. Freshwater biota and rising pCO2? Ecology Letters, 2016, 19(1), 98-108. http://dx.doi. org/10.1111/ele.12549. PMid:26610406.

HUTCHINS, D.A., FU, F.X., ZHANG, Y., WARNER, M.E., FENG, Y., PORTUNE, K., BERNHARDT, P.W. and MULHOLLAND, M.R. CO2 control of Trichodesmium N2 fixation, photosynthesis, growth rates, and elemental ratios: implications for past, present, and future ocean biogeochemistry. Limnology and Oceanography, 2007, 52(4), 1293-1304. http:// dx.doi.org/10.4319/lo.2007.52.4.1293.

LOLADZE, I. Hidden shift of the ionome of plants exposed to elevated $\mathrm{CO} 2$ depletes minerals at the base of human nutrition. eLife. 2014, 3, 1-29. http:// dx.doi.org/10.7554/eLife.02245.

LOLADZE, I. Rising atmospheric CO2 and human nutrition: toward globally imbalanced plant stoichiometry? Trends in Ecology \& Evolution. 2002, 17(10), 457-461. https://doi.org/10.1016/S01695347(02)02587-9.

MARANGER, R., JONES, S. E. and COTNER, J. B. Stoichiometry of carbon, nitrogen, and phosphorus through the freshwater pipe. Limnology and Oceanography Letters, 2018, 3(3), 89-101. http:// dx.doi.org/10.1002/lol2.10080.

MCDONALD, C.P., STETS, E.G., STRIEGL, R.G. and BUTMAN, D. Inorganic carbon loading as a primary driver of dissolved carbon dioxide concentrations in the lakes and reservoirs of the contiguous United States. Global Biogeochemical Cycles, 2013, 27(2), 285-295. http://dx.doi. org/10.1002/gbc.20032. 
MONTEITH, D.T., STODDARD, J.L., EVANS, C.D., DE WIT, H.A., FORSIUS, M., HØGÅSEN, T., WILANDER, A., SKJELKVÅLE, B.L., JEFFRIES, D.S., VUORENMAA, J., KELLER, B., KOPÁCEK, J. and VESELY, J. Dissolved organic carbon trends resulting from changes in atmospheric deposition chemistry. Nature, 2007, 450(7169), 537-U9. http:// dx.doi.org/10.1038/nature06316. PMid:18033294.

NOACCO, V., WAGENER, T., WORRALL, F., BURT, T.P. and HOWDEN, N.J.K. Human impact on long-term organic carbon export to rivers. Journal of Geophysical Research. Biogeosciences, 2017, 122(4), 947-965. http://dx.doi.org/10.1002/2016JG003614.

OU, M., HAMILTON, T.J., EOM, J., LYALL, E.M., GALLUP, J., JIANG, A., LEE, J., CLOSE, D.A., YUN, S.-S. and BRAUNER, C.J. Responses of pink salmon to CO2-induced aquatic acidification. Nature Climate Change, 2015, 5(10), 950-955. http://dx.doi. org/10.1038/nclimate2694.

PASTOR, J., SOLIN, J., BRIDGHAM, S.D., UPDEGRAFF, K., HARTH, C., WEISHAMPEL, P. and DEWEY, B. Global warming and the export of dissolved organic carbon from boreal peatlands. Oikos, 2003, 100(2), 380-386. http://dx.doi. org/10.1034/j.1600-0706.2003.11774.x.

PHILLIPS, J.C., MCKINLEY, G.A., BENNINGTON, V., BOOTSMA, H.A., PILCHER, D.J., STERNER, R.W. and URBAN, N.R. The Potential for CO2 -induced acidification in freshwater: a great lakes case study. Oceanography (Washington, D.C.), 2015, 28(2), 136-145. http://dx.doi.org/10.5670/ oceanog.2015.37.

PHILLIPS, K.N., GODWIN, C.M. and COTNER, J.B. The effects of nutrient imbalances and temperature on the biomass stoichiometry of freshwater bacteria. Frontiers in Microbiology, 2017, 8, 1692. http://dx.doi.org/10.3389/fmicb.2017.01692. PMid:28943865.

RAUBENHEIMER, D., MACHOVSKY-CAPUSKA, G.E., GOSBY, A.K. and SIMPSON, S. Nutritional ecology of obesity: from humans to companion animals. British Journal of Nutrition, 2015, 113(Suppl), S26-S39. http://dx.doi.org/10.1017/ S0007114514002323. PMid:25415804.

RAYMOND, P.A., HARTMANN, J., LAUERWALD, R., SOBEK, S., MCDONALD, C., HOOVER, M., BUTMAN, D., STRIEGL, R., MAYORGA, E., HUMBORG, C., KORTELAINEN, P., DÜRR, H., MEYBECK, M., CIAIS, P. and GUTH, P. Global carbon dioxide emissions from inland waters. Nature, 2013, 503(7476), 355-359. http://dx.doi. org/10.1038/nature12760. PMid:24256802.
RIEBESELL, U., BELLERBY, R.G.J., GROSSART, H.-P. and THINGSTAD, F. Mesocosm CO2 perturbation studies: from organism to community level. Biogeosciences, 2008, 5(4), 1157-1164. http:// dx.doi.org/10.5194/bg-5-1157-2008.

SCHOO, K.L., MALZAHN, A.M., KRAUSE, E. and BOERSMA, M. Increased carbon dioxide availability alters phytoplankton stoichiometry and affects carbon cycling and growth of a marine planktonic herbivore. Marine Biology, 2013, 160(8), 2145-2155. http://dx.doi.org/10.1007/s00227-012-2121-4.

STETS, E.G., STRIEGL, R.G., AIKEN, G.R., ROSENBERRY, D.O. and WINTER, T.C. Hydrologic support of carbon dioxide flux revealed by whole-lake carbon budgets. Journal of Geophysical Research, 2009, 114(G1), 114. http://dx.doi. org/10.1029/2008JG000783.

URABE, J., TOGARI, J. and ELSER, J.J. Stoichiometric impacts of increased carbon dioxide on a planktonic herbivore. Global Change Biology, 2003, 9(6), 818-825. http://dx.doi.org/10.1046/j.13652486.2003.00634.x.

URBAN, N., VERRY, E.S., EISENREICH, S., GRIGAL, D.F. and SEBESTYEN, S.D. Element cycling in upland/peatland watersheds. In: R.K. KOLKA, S.D. SEBESTYEN, E.S. VERRY and K.N. BROOKS, eds. Peatland biogeochemistry and watershed hydrology at the Marcell Experimental Forest. Boca Raton: CRC Press, 2011, pp. 213-241.

VAN DE WAAL, D.B., VERSCHOOR, A.M., VERSPAGEN, J.M.H., VAN DONK, E. and HUISMAN, J. Climate-driven changes in the ecological stoichiometry of aquatic ecosystems. Frontiers in Ecology and the Environment, 2010, 8(3), 145-152. http://dx.doi.org/10.1890/080178.

VAN DER PLOEG, R.R., BÖHM, W. and KIRKHAM, M.B. On the origin of the theory of mineral nutrition of plants and the law of the minimum. Soil Science Society of America Journal, 1999, 63(5), 1055. http:// dx.doi.org/10.2136/sssaj1999.6351055x.

WEISS, L.C., PÖTTER, L., STEIGER, A., KRUPPERT, S., FROST, U. and TOLLRIAN, R. Rising pCO2 in freshwater ecosystems has the potential to negatively affect predator-induced defenses in daphnia. Current Biology, 2018, 28(2), 327-332.e3. http://dx.doi. org/10.1016/j.cub.2017.12.022. PMid:29337079.

Received: 31 July 2019 Accepted: 18 October 2019 